\title{
Scaling with Paired Compression Method for Entrepreneurship Skills of Rural Youth in Agricultural Sector
}

\author{
M. Kavinila ${ }^{*}$, P. P. Murugan ${ }^{2 *}$, J. Pushpa ${ }^{1}$, J.S. Amarnath ${ }^{3}$ and K. Prabakaran ${ }^{3}$ \\ ${ }^{1}$ Department of Agricultural Extension and Rural Sociology, Agricultural College and \\ Research Institute, Madurai 625104 TN, India \\ ${ }^{2}$ Department of Agricultural Extension and Rural Sociology, Tamil Nadu Agricultural \\ University, Coimbatore 641003 TN, India \\ ${ }^{3}$ Department of Agricultural Economics, Agricultural College and Research Institute, \\ Madurai 625104 TN, India \\ *Corresponding author
}

\section{Keywords \\ Entrepreneurial skills, rural youth, paired comparison \\ Article Info \\ Accepted: \\ 20 August 2019 \\ Available Online: \\ 10 September 2019}

\section{A B S T R A C T}

\section{Introduction}

India has had a population growth of around 23 percent per decade resulting with current population of more than 1.2 billion. Half of the population in India is under 25 years of age and more than $65 \%$ below the age of 35 . The African Youth Charter defined, "youth" means "every person between the ages of 15 to 35 years". The young people are pillars to our tomorrow nation. Nowadays, many young people are interested in entrepreneurship and believe they have the ability to start their own businesses. Generally, rural youth are involving in agricultural activities starts from sowing to marketing. In addition to agriculture, they were also involved in allied activities like dairy, fisheries, cattle farming etc., there is the reason for young people are involve in entrepreneurial activities in agricultural sector.

An Entrepreneur is an individual with knowledge, skills, initiative, drive and spirit of innovation who aims at achieving goals. Entrepreneurship is the indivisible process flourishes, when the interlinked dimensions of individual psychological entrepreneurship, entrepreneur traits, social encouragement, business opportunities, government policies, 
availability of plenty of resources and opportunities coverage towards the common good, development of the society and economy. Entrepreneurship skills are an individual's ability to make business in a profit way. The lots of entrepreneurship skills are encompass to the entrepreneur, but some skills are highly influence to become successful entrepreneur. In this paper explain, the order of the important entrepreneurship skills for rural youth entrepreneurs in agricultural sector. The entrepreneurship skills were measure using paired comparison scaling method.

\section{Materials and Methods}

Scaling is the procedure of measuring and assigning the objects to the numbers according to the specified rules. Scaling is the process of generating the continuum, a continuous sequence of values, upon which the measured objects are placed.

The psychometric theory underlying the paired comparison method was developed by the American psychologist Louis Thurstone, who used it to investigate a wide range of psychological attributes. The Paired Comparison Scaling is a comparative scaling technique wherein the respondent is shown two objects at the same time and is asked to select one according to the defined criterion. The resulting data are ordinal in nature. (Edwards, 1969).

Table.1 Distribution of the Entrepreneurial skills with traits of rural youth in agriculture

\begin{tabular}{|l|l|l|}
\hline S. No & Skills & Traits \\
\hline $\mathbf{1 .}$ & Entrepreneurial key skills & $\begin{array}{l}\text { Innovative, initiative, creativity, risk taking, tolerance, hard } \\
\text { work, decision-making, problem- solving, achievement }\end{array}$ \\
\hline 2. & Marketing skills & $\begin{array}{l}\text { Trend marketing, Sales skill, commercial skill, negotiation } \\
\text { skill, marketing savvy, buyer persona, influencer marketing, } \\
\text { content marking, marketing strategy. }\end{array}$ \\
\hline $\mathbf{3 .}$ & Behavioral skills & $\begin{array}{l}\text { Self confidence, accept failure, persistence, passion, } \\
\text { motivation, independent, self efficacy, smart self promoter, } \\
\text { vision, perception. }\end{array}$ \\
\hline 4. & Business management skills & $\begin{array}{l}\text { Managerial skills, capacity planning, business launch, growth } \\
\text { management, strategic decisions, } \\
\text { organizational, goal setting, analyze and evaluate, competitive }\end{array}$ \\
\hline 5. & Human resources management skills & $\begin{array}{l}\text { Leadership skills, time management skills, communication } \\
\text { skills, information skills, group skills, network building, } \\
\text { customer care, collective skills, identification of opportunities, } \\
\text { management of family relationship skill. }\end{array}$ \\
\hline 6. & Economic resources skills & $\begin{array}{l}\text { Financial management, accountability, resource management } \\
\text { skills, quantity and quality control, economic management. }\end{array}$ \\
\hline 7. & Soft skills & $\begin{array}{l}\text { Listening skills, attentive, ethics, friendly, courteous, honest, } \\
\text { critical thinking, artistic sense, presentation, inspiring. }\end{array}$ \\
\hline
\end{tabular}

Method of collection of entrepreneurial skills

In this study Entrepreneurial skills are examine to the rural youth entrepreneurs. Based on the literatures nearly sixty three traits were collected and contributed for the entrepreneurial activities to the entrepreneurs. Those sixty three traits are classified under seven skills. The following skills were presented table.1. 


\section{Method of data collection tool}

The study was conducted in Dharmapuri, Kanchipuram, Thiruvallur districts of Tamil Nadu. These districts are only the important emerging industrialized cities but also with much of agriculture and allied activities and also more number of agro industries, fisheries, livestock productions, fertilizers and nursery activities.

Among these districts totally 210 rural youth entrepreneurs were selected by snow ball sampling technique. A well structured and pre -tested interview schedule was used to collect data by personal interview method. The measurement of the basic traits was made through the paired comparison method. Paired comparison method adopted by Edwards (1969) was used for this study. As per criteria set up by Edwards (1969) the method of complete data was followed in this case.

Seven entrepreneurship skills were arranged and the youth entrepreneurs were asked to place the state on it. Paired comparison method requires informants to assess the relative importance of different items. Matrix Ranking usually involves placing items in the order of importance whereas paired method assigned a value or a score to a specific item.

\section{Results and Discussion}

\section{Method of data analysis}

In this study 210 individuals were asked to make comparative judgments of the relative degree of favorableness of 7 skills relating to the participation of the basic traits of entrepreneurs. The 7 entrepreneurship skills were presented in all possible pairs so that each individual made $7(7-1) / 2=21$ comparative judgments. The schematic arrangements of the frequencies in which the cell entries correspond to the frequency with the column stimulus is judged more favorable than the row stimulus. After examination of these 7 skills, that, in general, a person who believed these statements probably had a more favorable attitude toward the participation of the skills for rural youth entrepreneurs than an individual who disagreed with the relative statements. E.g.: 40 Entrepreneurs state that, entrepreneurial key skills are more favorable than entrepreneurial skill for their entrepreneurial activities. At the same time 170 entrepreneurs who disagree with this statement.

Rearrange the stimuli in rank order least favorable to most favorable using sum of the row, of the F Matrix with the stimulus with the sum of the smallest row at the left and with the highest at the right. In interchanging any pair of columns must to take the corresponding interchange of the pair of rows. Table 2 gives the rearranged $F$ matrix or the frequency with which each column stimulus was judged more favorable than the row stimulus. i.e. human resource skills are more favorable than entrepreneurial key skills, which means 170 respondents judged and they feel comparatively entrepreneurial key skills better with human resource skills in their business.

The diagonal entries involving a comparison of each skill with itself assumed to be equal to $\mathrm{N} / 2$. The reciprocal of $N$ is $1 / 210=0.005$ multiplying the cell entries of table 2 by this reciprocal. It may be $170 * 0.05=0.810$. The Pmatrix entries are shown obtained. Following the P-matrix values $\mathrm{Z}$ - matrix values are entered by using $\mathrm{Z}$ table value.

\section{Scale value}

In this research, the results of the scaling belonging to the entrepreneurship skills for the rural youth entrepreneurs in the agricultural sector are presented using the paired comparison method. By moving the starting point of the axis of the $\mathrm{Z}$ values of the scale values were obtained. Finally, the obtained 
scale values are shown in the number line.

From figure 1 explain which orders that the entrepreneurship skills of the rural youth entrepreneurs should possess from the most wanted to the least wanted, we see that human resource skills were scored in the first order.

Most of Rural youth were state that, in the business Leadership skills, time management skills, communication skills, network buildings, customer care, identification of opportunities are most important traits and it is lead to be a business in a successful way. This might be due to the reason for taking first order of importance and following that Entrepreneurial key skills were placed to the second order of the importance. The least order of importance skill is economic skill.

The Internal Consistency Check
The scale value of the 7 skills on a least to most favorable psychological continuum, an internal consistency check may be applied.

This check involves determining how well our observed or empirical proportions $\mathrm{P}$ matrix agree with those to be expected in terms of our derived scale values. The first step is to obtain a matrix $\mathrm{Z}_{\mathrm{ij}}{ }^{1}$ matrix of theoretical normal deviates corresponding to the scale separations of the traits.

If we subtract, in order, the entries at the left of the table from the scale value for stimulus 1 at the top of column. Similarly, if we subtract, in order, the entries at the left of the table from the scale value for stimulus 2 at the top of column, we obtain theoretical normal deviates above the diagonal for column. The other entries in table are obtained same manner.

Table.2 Distribution of the F Matrix for 7 skills judged by 210 rural youth entrepreneurs

\begin{tabular}{|l|l|l|l|l|l|l|l|}
\hline & $\begin{array}{l}\text { Human } \\
\text { resource } \\
\text { skills }\end{array}$ & $\begin{array}{l}\text { Entrepreneu } \\
\text { rial } \\
\text { skills }\end{array}$ & $\begin{array}{l}\text { Behavio } \\
\text { ral } \\
\text { skills }\end{array}$ & $\begin{array}{l}\text { Marketi } \\
\text { ng skills }\end{array}$ & $\begin{array}{l}\text { Soft } \\
\text { skills }\end{array}$ & $\begin{array}{l}\text { Business } \\
\text { manageme } \\
\text { nt skills }\end{array}$ & $\begin{array}{l}\text { Economic } \\
\text { resources } \\
\text { skills }\end{array}$ \\
\hline Human & $\mathbf{1 0 5}$ & 170 & 180 & 185 & 180 & 191 & 193 \\
\hline Entrepreneurial & 40 & $\mathbf{1 0 5}$ & 156 & 159 & 167 & 173 & 186 \\
\hline Behavioral & 30 & 54 & $\mathbf{1 0 5}$ & 154 & 164 & 165 & 168 \\
\hline Marketing & 25 & 51 & 56 & $\mathbf{1 0 5}$ & 154 & 168 & 172 \\
\hline Soft skills & 30 & 43 & 46 & 56 & $\mathbf{1 0 5}$ & 156 & 160 \\
\hline Business & 19 & 37 & 45 & 42 & 54 & $\mathbf{1 0 5}$ & 162 \\
\hline Economic & 17 & 24 & 42 & 38 & 50 & 48 & $\mathbf{1 0 5}$ \\
\hline
\end{tabular}

\begin{tabular}{|l|l|l|l|l|l|l|l|}
\hline & $\begin{array}{l}\text { Economic } \\
\text { resources } \\
\text { skills }\end{array}$ & $\begin{array}{l}\text { Business } \\
\text { management } \\
\text { skills }\end{array}$ & $\begin{array}{l}\text { Soft } \\
\text { skills }\end{array}$ & $\begin{array}{l}\text { Marketi } \\
\text { ng skills }\end{array}$ & $\begin{array}{l}\text { Behavior } \\
\text { al skills }\end{array}$ & $\begin{array}{l}\text { Entrepreneu } \\
\text { rial } \\
\text { skills }\end{array}$ & $\begin{array}{l}\text { Human } \\
\text { resource } \\
\text { skills }\end{array}$ \\
\hline Economic & $\mathbf{1 0 5}$ & 40 & 30 & 25 & 30 & 19 & 17 \\
\hline Business & 170 & $\mathbf{1 0 5}$ & 54 & 51 & 43 & 37 & 24 \\
\hline Soft skills & 180 & 156 & $\mathbf{1 0 5}$ & 56 & 46 & 45 & 42 \\
\hline Marketing & 185 & 159 & 154 & $\mathbf{1 0 5}$ & 56 & 42 & 38 \\
\hline Behavioral & 180 & 167 & 164 & 154 & $\mathbf{1 0 5}$ & 54 & 50 \\
\hline $\begin{array}{l}\text { Entrepreneuria } \\
\text { l }\end{array}$ & 191 & 173 & 165 & 168 & 156 & $\mathbf{1 0 5}$ & 48 \\
\hline Human & 193 & 186 & 168 & 172 & 160 & 162 & $\mathbf{1 0 5}$ \\
\hline
\end{tabular}


Table.3 Distribution of the $Z$ matrix corresponding to the $P$ matrix of value (using $\mathrm{z}$ table)

\begin{tabular}{|l|l|l|l|l|l|l|l|}
\hline & $\begin{array}{l}\text { Human } \\
\text { resource } \\
\text { skills }\end{array}$ & $\begin{array}{l}\text { Entrepreneur } \\
\text { ial key skills }\end{array}$ & $\begin{array}{l}\text { Behavioral } \\
\text { skills }\end{array}$ & $\begin{array}{l}\text { Marketin } \\
\text { g skills }\end{array}$ & $\begin{array}{l}\text { Soft } \\
\text { skills }\end{array}$ & $\begin{array}{l}\text { Business } \\
\text { manageme } \\
\text { nt skills }\end{array}$ & $\begin{array}{l}\text { Economic } \\
\text { resources } \\
\text { skills }\end{array}$ \\
\hline Human & $\mathbf{0 . 0 0 0}$ & 0.878 & 1.067 & 1.18 & 1.067 & 1.341 & 1.398 \\
\hline $\begin{array}{l}\text { Entrepreneuria } \\
\text { I }\end{array}$ & -0.878 & $\mathbf{0 . 0 0 0}$ & 0.653 & 0.697 & 0.824 & 0.931 & 1.206 \\
\hline Behavioral & -1.067 & -0.653 & $\mathbf{0 . 0 0 0}$ & 0.622 & 0.776 & 0.793 & 0.842 \\
\hline Marketing & -1.18 & -0.697 & -0.622 & $\mathbf{0 . 0 0 0}$ & 0.622 & 0.842 & 0.912 \\
\hline Soft skills & -1.067 & -0.824 & -0.776 & -0.622 & $\mathbf{0 . 0 0 0}$ & 0.653 & 0.713 \\
\hline Business & -1.341 & -0.931 & -0.793 & -0.842 & -0.653 & $\mathbf{0 . 0 0 0}$ & 0.742 \\
\hline Economic & -1.398 & -1.206 & -0.842 & -0.912 & -0.713 & -0.742 & $\mathbf{0 . 0 0 0}$ \\
\hline sums & $\mathbf{- 6 . 9 3 1}$ & $\mathbf{- 3 . 4 3}$ & $\mathbf{- 1 . 3 1}$ & $\mathbf{0 . 1 2}$ & $\mathbf{1 . 9 2}$ & $\mathbf{3 . 8 2}$ & $\mathbf{5 . 8 1}$ \\
\hline MEANS & $\mathbf{- 0 . 9 9 0}$ & $\mathbf{- 0 . 4 9 0}$ & $\mathbf{- 0 . 1 8 8}$ & $\mathbf{0 . 0 1 8}$ & $\mathbf{0 . 2 7 5}$ & $\mathbf{0 . 5 4 5}$ & $\mathbf{0 . 8 3 0}$ \\
\hline $\mathbf{0 . 9 9 0}$ & 0.000 & 0.500 & 0.802 & 1.008 & 1.265 & 1.535 & 1.820 \\
\hline
\end{tabular}

Table.4 Theoretical Normal Deviates $\mathrm{Z}_{\mathrm{ij}}{ }^{1}$ corresponding to the scale distance between the statements of Table 3 (eg: $Z_{11}=S_{1}-S_{2}$ )

\begin{tabular}{|l|l|l|l|l|l|l|l|l|}
\hline & & $\mathbf{1}$ & $\mathbf{2}$ & $\mathbf{3}$ & $\mathbf{4}$ & $\mathbf{5}$ & $\mathbf{6}$ & $\mathbf{7}$ \\
\hline & SCALEVALUE & 0.000 & 0.500 & 0.802 & 1.008 & 1.265 & 1.535 & 1.820 \\
\hline $\mathbf{1}$ & 0.000 & & & & & & & \\
\hline $\mathbf{2}$ & 0.500 & -0.500 & & & & & & \\
\hline $\mathbf{3}$ & 0.802 & -0.802 & -0.302 & & & & & \\
\hline $\mathbf{4}$ & 1.008 & -1.008 & -0.508 & -0.206 & & & & \\
\hline $\mathbf{5}$ & 1.265 & -1.265 & -0.765 & -0.463 & -0.257 & & & \\
\hline $\mathbf{6}$ & 1.535 & -1.535 & -1.035 & -0.733 & -0.527 & -0.270 & & \\
\hline
\end{tabular}

Fig.1

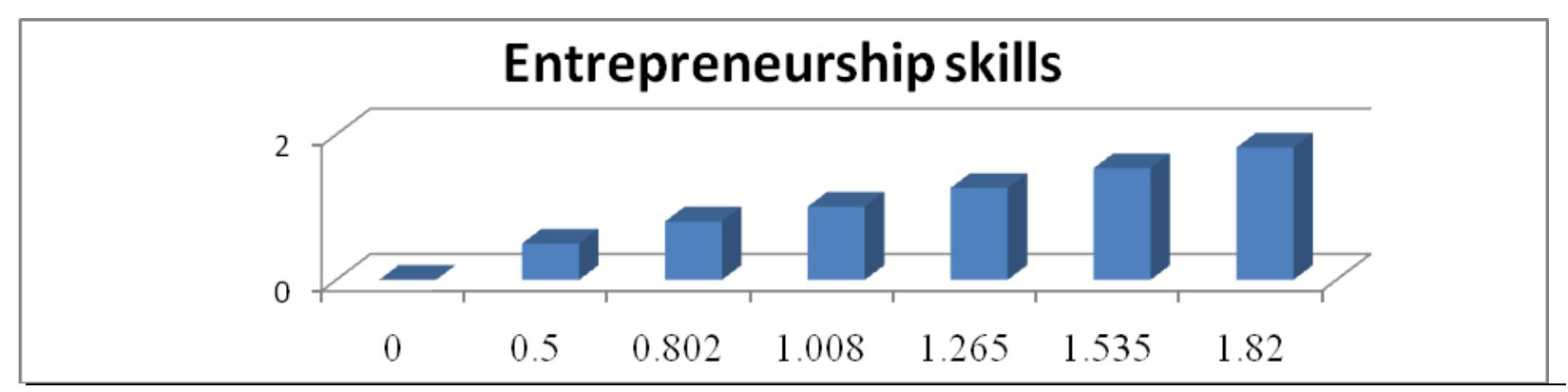

After that using the Theoretical Normal Deviates $\mathrm{Z}_{\mathrm{ij}}{ }^{1}$ cell entries values we enter the $\mathrm{z}$ table value for the $P_{i j}{ }^{1}$
Following that the entries in the $\mathrm{P}$ matrix from the corresponding entries in the $P_{i j}{ }^{1}$ from the corresponding entries in the $\mathrm{P}_{\mathrm{ij}}$ matrix, that is 
subtract the entries of $\mathrm{P}$ matrix entries from the corresponding independence entries of the $P_{i j}{ }^{l}$, we will obtain the discrepancies between our empirical proportions with which we started and our theoretical proportions. Using the sum of the discrepancies between the theoretical proportions $P_{i j}{ }^{l}$ and observed proportion value $\mathrm{P}_{\mathrm{ij}}$ the sum of the absolute values and dividing by the number of discrepancies, we have the absolute average discrepancy, thus

$$
\mathrm{AD}=\sum \boldsymbol{P}_{i j}-\boldsymbol{P}_{i j}{ }^{1}
$$

The absolute average discrepancy of 0.07 for the 7 traits is slightly larger than the values usually reported when stimuli are scaled by the method of paired comparison.

Paired comparison is powerful decision making tool. Thus, paired comparison value in entrepreneurial skills of rural youth is proposed based on the analysis that more comparisons on nearby pairs could generate accurate with efficient results. The result focused more value skill of entrepreneurs felt that more favored to least favored. In future studies to be use and focus entrepreneurs need based training programme, government schemes, policies etc.

\section{Acknowledgment}

I sincerely thank to Indian council of Social Science Research Institute for their contributing fund thorough the fellowship of ICSSR administrative doctoral fellowship for the period (2017-2019) of research work.

\section{References}

Ajani, E. N, Mgbenka, R. N, and Onah, O.(2015) "Empowerment of Youths in Rural Areas through Agricultural Development Programmes: Implications for Poverty Reduction in Nigeria". International Journal of Research in Agriculture and Forestry Volume 2, Issue 2, February 2015, PP 34-41, ISSN 2394-5907.

David, H. A. (1963). The method of paired comparisons (Vol. 12). London.

Edwards, A.L., Techniques of attitude scale construction. Vakils, Feffer and Simons private ltd. Bombay. (1969).

GEM (2012), “2011 Global Report”, edited by D.J. Kelley, S. Singer \& M.D. Herrington.

Kourilsky, M. and Walstad, W. (2007) The Entrepreneur in Youth, Cheltenham: Edward Elgar.

Likert, R.A., A technique for the measurement of attitude. Arc. Psycho. (1932)

National Youth Policy, 2012. Ministry of Youth Affairs and Sports, Government of India.

Silverstein, D. A., \& Farrell, J. E. (2001). Efficient method for paired comparison. Journal of Electronic Imaging, 10(2), 394-399.

Thilagam, J. 2012. Indicators of agri entrepreneurship and evaluation of business planning and development unit-A diagnostic study, Unpublished. M.Sc.(Ag) Thesis, AC\&RI, TNAU, Coimbatore.

\section{How to cite this article:}

Kavinila, M., P. P. Murugan, J. Pushpa, J. S. Amarnath and Prabakaran, K. 2019. Scaling with Paired Compression Method for Entrepreneurship Skills of Rural Youth in Agricultural Sector. Int.J.Curr.Microbiol.App.Sci. 8(09): 1885-1890. doi: https://doi.org/10.20546/ijcmas.2019.809.218 